\title{
The Evaluation of Mathematical Teacher Ability In Defining The Minimum Completeness Criteria Using The Google Form
}

\author{
Estu Subekti ${ }^{1}$, Ani Rusilowati ${ }^{2}$, Muhammad Khumaedi ${ }^{2}$ \\ \{bektiestu@gmail.com¹, rusilowati@yahoo.com², muhammad_khumaedi@mail.unnes.ac.id²\} \\ SMP Negeri 1 Greged Kabupaten Cirebon Jawa Barat, Indonesia ${ }^{1}$, Graduate School, Universitas Negeri \\ Semarang ${ }^{2}$
}

\begin{abstract}
This study aims to determine the ability of elementary school and junior high school level mathematics teachers towards minimum completeness criteria using google form. The teacher is the most important component in the development of the world of education with the task of educating, teaching, fostering, directing, training and evaluating students. The ability of the teacher to determine the minimum completeness criteria is known through the ability to define complexity, carrying capacity and intake of students. This study uses descriptive analytical methods with data collection techniques in the form of questionnaires. The research subjects were elementary school teachers and junior high school teachers. Based on the results of the google form research, it is one of the applications recommended as an online assessment tool. Teachers with 7 years of teaching experience have the ability to determine math scores as a provision made at the beginning of the school year.
\end{abstract}

Keywords: minimum completeness criteria, google form, teacher

\section{Introduction}

The success of students can be viewed from the ability of students to exceed the minimum completeness criteria. The minimum completeness criteria are the lowest value for stating students achieve completeness. One indicator of the success of students in learning is if the average learning outcomes have reached the minimum specified completeness criteria [1]. Determination of minimum completeness criteria for learning is the initial stage of the implementation of assessment of learning outcomes as part of the steps to develop the curriculum. Learning and learning are practice-based approaches where teaching experience and academic skills are interrelated in many ways [2]. A competency-based curriculum that uses criteria references in assessments requires educators and education units to set minimum criteria that become benchmarks for achieving competency. Each education unit needs to disseminate minimum completeness criteria so that information can be easily accessed by students and or their parents [3]. The minimum completeness criteria are determined by the education unit based on the results of the subject teacher discussion in the education unit or some educational units that have almost the same characteristics. The education unit has the function of regulating the occurrence of teaching and learning in the classroom [4]. 
The teacher is the most important component in the development of the world of education with the main tasks, namely: educating, teaching, fostering, directing, training and evaluating students. The teacher carries out the process of testing, interpreting the results and operationalizing the findings in order to make decisions and take action

in response to student test results [5]. The teacher carries out duties and functions with professionals by applying the teacher's code of ethics correctly. The task of the teacher is not only as a provider of knowledge but also creates learning situations to produce

learning experiences and influence the creativity of students [6]. Learning activities that are managed by the teacher can find out the abilities possessed by students in achieving the specified competencies. Interest in gaining knowledge related to the competencies and abilities of students in developing is very important for the future [7]. There are four things that need to be considered by the teacher in implementing the evaluator's functions, namely: (1) evaluation must be carried out on all aspects of student development, both cognitive, affective and psychomotor aspects; (2) evaluation must be carried out continuously; (3) evaluation is carried out by using various assessment instruments; (4) evaluation must be conducted openly by involving students as evaluators [8].

Determination of the minimum completeness criterion value is done through minimal learning completeness analysis on each indicator by paying attention to the complexity, carrying capacity, and intake of students to achieve the completeness of basic competencies and competency standards. Four identity indicators, which have been elaborated and organised thematically, related to the teacher's engagement and critical alignment in the community of participants: (1) Positioning in relation to pupils, (2) Reflecting on developing a workshop model in teaching, (3) Integrating and expanding models of teaching and (4) Challenging positioning in relation to didacticians [9]. Complexity is the difficulty level of subject matter including indicators, basic competencies and competency standards that must be achieved by students. To achieve success the teacher must fully understand the material being taught and is required to know exactly where the position of students' knowledge at the beginning follows certain material [10]. Carrying capacity is the ability of supporting resources in the implementation of learning in each school, a high carrying capacity indicator if the school has good infrastructure but low carrying capacity if the school does not have poor facilities in the learning process. The level of ability of the students in the school concerned is based on the results of the selection at the time of the acceptance of new students, the value of the national exam / school. One of the teacher's abilities that must be mastered is to determine the minimum completeness criteria because the assessment of students must pay attention to the differences of complete learning-based individuals [11].

In applying in the field the existence of graduation policy, the principal instructs the teacher to raise the competency threshold so that the teacher must inevitably increase the value of the aspects of complexity, carrying capacity and intake of the students. For simplicity, most teachers estimate the value of aspects in the completeness criteria to be minimal so that the value of the supporting aspects in determining the minimum completeness criteria becomes invalid. In reality it is not uncommon to find the minimum completeness criteria set that cannot be fulfilled because the preparation and determination is not quite right [12]. The ability of teachers to understand aspects of complexity, supportive capacity and intake of students can be an alternative in the preparation and determination of minimum completeness criteria. Assessment relates to learning improvement and support the use of various strategies and tools in assessing students [13]. 
Referring to the description above, to find out the problem of determining the minimum completeness criteria for subjects set at the beginning of the school year, it is necessary to evaluate the ability of teachers to understand aspects of minimum completeness criteria including the complexity, carrying capacity and intake of students. Identifying the constituents contained in the minimum completeness criteria by defining aspects becomes indicator items. Teachers' awareness of guidelines improve assessment literacy and increase the appropriateness of teacher-based practices involving the use of test scores [14]. The google form application is used as a medium to determine the teacher's ability to understand the indicator items that make up every aspect of the minimum completeness criteria.

\section{Methods}

This research uses descriptive analysis method by distributing surveys to gather information from respondents, namely mathematics teachers. The research procedure consists of: (1) preparation and review of literature, (2) developing research instruments, (3) distributing and collecting questionnaires, and (4) conducting data analysis and analysis. This research is by distributing surveys to gather information from respondents.

The subjects of this study were elementary and junior high school level mathematics teachers. Primary school teachers come from Cirebon city and junior high school teachers come from Cirebon district. The distribution of questionnaires began on January 28 to February 25, 2019, with the hope that quite a number of respondents could participate in this research. The sample of this study is teachers who teach in different schools in the city and regency of Cirebon.

Data collection methods needed in this study are questionnaires and document studies. The type of questionnaire used in this study is a closed questionnaire with alternative answers that have been provided using a Likert scale. The component that was asked in this questionnaire was the identity of the respondent who asked for the name, employee and class master number which was provided in the first part, the ability to understand the complexity aspects consisting of 3 indicators, the ability to understand aspects of carrying capacity consisting of 5 indicators and the ability to understand the intake aspects students consisting of 2 indicators are in the second part.

Google form is used as a tool to find out the ability of teachers to understand the definition of minimum completeness criteria for subjects. The teacher's response data to the teacher's ability assessment tool was obtained by giving questionnaires to respondents using interactive services based on whatsapp playstore applications installed in smartphon.

The method of analysis of this study was carried out by: 1) classifying the average score of the teacher's answer on the questionnaire based on the Likert scale category, 2) looking for the percentage of teacher response results, 3) interpreting teacher answers based on the percentage results.

\section{Results and Discussion}

Teachers are an important factor in the success of using Google Form as a media for assessing the ability of teachers to understand the definition of indicators in the aspects of minimal completeness criteria. Judging from the competence of the teacher in using the 
google form shows that the teacher is able to use the Whatsapp application in answering the questionnaire. Teacher response data about the use of online questionnaires as a medium for assessing teacher ability shows that the results of teacher responses in answering questions in online questionnaires at the same time. The process of clarification in answering online questionnaires shows the teacher's desire to learn to understand the questions contained in the online questionnaire.

The questionnaire using Google Form has facilities that can be accessed online so that it is effective and efficient in filling and analyzing data. Instructions for use can be informed to the respondent in the questionnaire form to provide information about the procedures for giving responses to the online questionnaire using the google form. The web-based google form application can respond quickly to questionnaires wherever they are using a laptop or mobile [15]. Information given to respondents so that the questionnaire is responded by telling directly using the application message whatsaap. The questionnaire was addressed directly to the teacher as the respondent by directly sending the draft / link made directly in the form of whatsaap and the request to the respondent to give a response.

The instructions for filling out the questionnaire are briefly explained so that the respondent can understand the questions in the questionnaire. After the respondent fills out the identity and answers the questions in the questionnaire, the respondent can end filling out the questionnaire by clicking the submit button in the lower left. The results of respondents' responses to online questionnaires using Google Form can be downloaded in the form of microsoft excel files. Display in Microsoft Excel files can display all answers, respondent's identity and time when filling out the questionnaire using Google Form.

In this study the results of respondents' responses to online questionnaires using google form are presented in Figure 1. The aspects of minimum completeness criteria assessed in the questionnaire are complexity with indicators: (1) educators master knowledge and abilities in accordance with the field being taught, (2) students are skilled at applying concepts, (3) long enough to understand the material so that the learning process requires repetition. An indicator is said to have a high level of complexity when in its achievement it needs to be supported by components with a number of conditions [16]. Carrying capacity with indicators: (1) availability of educators and education personnel, (2) facilities and infrastructure including libraries and laboratories, (3) school management, (4) tools and materials in the learning process, (5) school stakeholder awareness. In the physical aspect, the infrastructure to support education is not fully adequate [17]. Intake of students with indicators: (1) student competencies in the form of school exam / USBN scores, (2) the value of previous class report cards. 


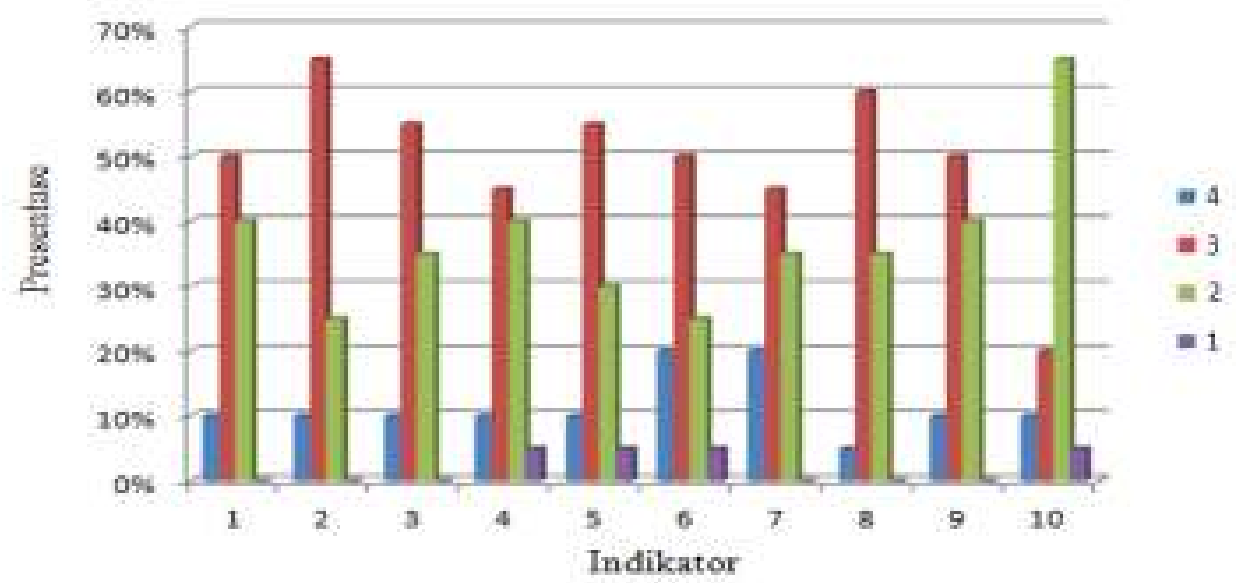

Figure 1. Assessment of the teacher's ability to understand Minimal Completion Criteria

In figure 1 , it can be seen that the teacher's ability to understand the indicators that comprise each aspect in the minimum completeness criteria is understood to be $49.5 \%$, very understanding at $11.5 \%$, quite understanding $37 \%$ and not understanding at $2 \%$. The ability of teachers to answer 10 questions in aspects of complexity, carrying capacity and intake of students is seen in each question not dominated by one answer choice. A competency-based curriculum that uses the criteria reference in the assessment requires the educator and the education unit to set minimum completeness criteria with analysis and pay attention to the mechanism, namely the principle and steps of determination [18].

There is one question in the questionnaire answered by the teacher with quite understandable answers to the aspects of student intake that refer to the value of students as indicators in the preparation of minimum completeness criteria. The value of students if they are still at the same school level can be seen as a report card in the previous class but if the value of students from elementary school to junior high school there is a possibility of reluctance in making average grades in the class as an indicator in the preparation of minimum subject values.

\section{Conclusion}

The ability of elementary and junior high school level mathematics teachers to have a good ability/ understanding in understanding aspects of minimum completeness criteria includes complexity, carrying capacity and intake of students. Teachers with a 7-year teaching experience have the ability to determine minimum criteria that become a benchmark for achieving subject competencies.

Google form can be one of the recommended applications for making online assessment tools. The response to the use of google form as an alternative assessment provides good benefits for teachers and researchers. The use of google form can be used in educational tasks, such as collecting student / teacher data, making online registration forms for schools, distributing questionnaires to parents of students online and gathering opinions from others. 


\section{References}

[1] Khumaedi, M.: Evaluasi Belajar Kompetensi Menggambar Roda Gigi Lurus Mahasiswa Pendidikan Teknik Mesin Universitas Negeri Semarang. Jurnal Pendidikan Teknik Mesin, 15(1) pp. 23-29 (2015).

[2] Thorsten, P. J.A.: Experiences From The Teacher-Researcher's Perspective On Learning Study Challenges and opportunities. Emerald Insight, 6(1).pp. 45 - 55 (2017).

[3] Mesrawati.: Meningkatkan Kemampuan Guru Dalam Menetapkan Kriteria Ketuntasan Minimal (KKM) Di SD Negeri 018 Rambah Melalui Kelompok Kerja Guru Sekolah. Jurnal Pendidikan Rokania, 1(2) pp. 31-42 (2016).

[4] Palma, J.P., Juvy S. Reyes, J.S.: Students' Concerns And Issues On Teachers And Teaching. International Journal Of Education And Research, 7(2), pp.145-158 (2019).

[5] Pitts, R. T., \& Naumenko, O.: The 2014 Standards for Educational and Psychological Testing:What Teachers Initially Need to Know. Working Papers in Education, 2(1),pp.1-6 (2016).

[6] Ghodang, H.: Teacher's Performance Model In Public Senior High School In Medan. International Journal of Education and Research, 7(6), pp.229-236 (2019).

[7] Rovio, A., Johansson.: Variation in approaches to lesson analysis - alternative tools for the reconstruction of teaching. Emerald Insight, 1(9),pp.1-11 (2018).

[8] Sanjaya, W.: Strategi pembelajaran berorientasi standar proses pendidikan. Jakarta: Kencana (2011).

[9] Bjuland, R., Cestari, M. L., Borgersen, H. E.: Professional mathematics teacher identity: analysis of reflective narratives from discourses and activities. J Math Teacher Educ, $15 \mathrm{pp}$. 405-424 (2012).

[10] Setyawardani, D., Rusilowati, A., Hartono.: Pengembangan Alat Evaluasi Proposition Generating Task untuk mengukur Struktur Kognitif Siswa di SMA. Journal of Innovative Science Education, 1(2) pp. 85-91 (2012).

[11] Pribadi, S.: Kegiatan Workshop Dengan Metode Kolaboratif Dan Konsultatif Sebagai Upaya Meningkatkan Kemampuan Guru Dalam Menetapkan KKM. Jurnal Ilmiah Mitra Swara Ganesha, 3(1) pp. 16-30 (2016).

[12] Widodo.: Mencapai Kriteria Ketuntasan Minimal Menggunakan Bilangan Baku. Jurnal Pendidikan Penabur, 8(13) pp. 30-41 (2009).

[13] Batubara, H.: Penggunaan Google Form Sebagai Alat Penilaian Kinerja Dosen Diprodi PGMI UNISKA Muhammad Arsyad Al Banjari. Jurnal Pendidikan Dasar Islam, 8(1) pp. 39-50 (2016).

[14] Azis, A.: Teachers' Conceptions And Use Of Assessment In Student Learning. Indonesian Journal Of Applied Linguistics, 2(1), pp. 41-51, (2012).

[15] Pitts, R., T.: The 2014 Standards for Educational and Psychological Testing: What Teachers Initially Need to Know. Working Papers in Education, 2(1), pp. 1-6, (2016).

[16] Nuraisiah.: Upaya Meningkatkan Kemampuan Guru dalam Menetapkan Kriteria Ketuntasan Minimal Melalui Workshop dan Pendampingan di SD Negeri 1 Mataram. Jurnal Media Bina Ilmiah, 11(12) pp. 53-60 (2017).

[17] Busono, T.: Evaluasi Pemenuhan Standar Minimal Sarana Dan Prasarana Pendidikan Dasar Di Kota Bandung. Jurnal Invotec, 7(1) pp. 81 - 91 (2011).

[18] Mariana.: Meningkatkan Kemampuan Guru Dalam Menetapkan Kriteria Ketuntasan Minimal (KKM) Di SD Negeri 007 Rambah Melalui Kelompok Kerja Guru Sekolah (KKGS). Jurnal Ilmiah Edu Research, 6(2) pp.13-21 (2017). 